\title{
THE DYNAMICS SPILLOVER OF TRADE BETWEEN INDONESIA AND ITS COUNTERPARTS IN TERMS OF AFTA 2015 : A MODIFIED GRAVITY EQUATION APPROACH
}

\author{
Barli Suryanta
}

\begin{abstract}
The forthcoming 2015, ASEAN is being confident to implement ASEAN Free Trade (AFTA). The existence of AFTA is to outstrip trade liberalization due to augment trade volume significantly and transaction easing as well among the members of AFTA, mainly by inducing lower tariffs some certain commodities up to $0 \%$. This paper is conducted in order to examine on what prominent commodity of Indonesia compared to its counterparts namely Brunei, Malaysia, Philippines, Singapore and Thailand. These Indonesia counterparts are selected therefore they were the founding of ASEAN. Furthermore, this paper utilizes a modified Gravity Equation model. This robust model has an effort to estimate the significance of some parameters of variable from model equation. Thus, it can be detected that what are from these variables from a model equation being as a key determination factor to influence trading transactions. This paper also assesses the adjusted $R$-squared due to which Indonesia counterparts incur some vantage points as well as beneficial for Indonesia in terms of AFTA. The novelty contribution of this paper is to reveal the dynamics trade spillover between Indonesia some strategic sectors and its counterparts. By doing so, Indonesia is expected to be a dominant player in AFTA 2015 and taking some advantageous from AFTA into Indonesia account.
\end{abstract}

Keywords: AFTA 2015, a modified gravity equation model, analysis of data panel JEL Classification: C33, C51, F15

1 Corresponding author: A Junior Lecturer and a Researcher at the School of Business and Management, InstitutTeknologi Bandung (SBM ITB), Indonesia; tel. +62-22-2531923; email: barli.suryanta@sbm-itb.ac.id 


\section{INTRODUCTION}

In the autarky situation, Indonesia has free to choose the beneficial partners for trade outside ASEAN. Nonetheless, since 1992 until today, the condition had been significantly altered by the existence of AFTA. The founding members, namely Indonesia, Thailand, Malaysia, Singapore, and Philippines and also plus Brunei were being the first group to utilize Common Effective Preferential Tariff (CEPT) Scheme. The CEPT by the terminology is a cooperative arrangement among ASEAN Member States that will reduce intra-regional tariffs and remove non-tariff barriers over a 10-year period commencing January 1, 1993 (asean.org). Then, the second group which has composed of Cambodia, Lao, Myanmar, and Vietnam would allow to possess the same CEPT as the first group under different circumstances and it might be initially after the first group is inferred establishing to some extent.

Moreover, while the strategy of the CEPT is still on the track, in as much, ASEAN already has built two new commitments to foster the economic integration in ASEAN through ASEAN Economics Community (AEC) Blueprint 2008 and AEC chart-book 2009. In this both scheme, the essence is the priority sector to be fully integrated in year 2015. Regarding these accords, ASEAN featured seven sectorswhich are compatible with ASEAN competitive advantage in the foreseeable future. The seven sectors are agro-based products, automotive, electronics, fisheries, rubber-based products, textiles and apparels, wood-based products. Nevertheless, this paper would be determining the selected sectors such agro-based sector, fisheries, rubber basedproducts, and wood based products. These sectors are chosen because actually, Indonesia possesses more competitive advantage of these rather than its competitor.

Linkage to this context, this paper has a purpose to assess these selected sectors. Most importantly, the novelty of this paper is to define whether the strength sector or the weakness sector, even the poor sector comparing Indonesia to its selected ASEAN trading partners, namely Malaysia, Philippines, Singapore, Thailand and Brunei in accordance with AFTA 2015. Furthermore, to develop the rigorous analysis, this paper employs a modified Gravity Equation model. This model has a function to describethe robustness of the interpretation from theresulted regression due to the significant coefficients of the variable and the adjusted R-squareas well. Thus, this study can spill the dynamics terms of trade between Indonesia and others in proper way.

The next session of this paper outline the theory of economic integration, session two discuss the methodology and the data used, while the estimation result of the gravity model and its analysis is presented in session 4. Conclusion and implication of this study is presented on the last session, and will close the presentation of this paper. 


\section{THEORY}

\section{The Economic Integration}

Venables (2000) said that economic integration called as a regional economic integration which occurs when countries come together to form free trade areas or customs unions, offering members preferential trade access to each other' market. He emphasizes regional integration into 'deeper integration in terms of international trade' that it can be pursued by going beyond abolition of import tariffs and quotas, to further measures to remove market segmentation and promote integration. Economic integration is defined as the elimination of economic frontiers between two or more economies (Pelksman, 2006). He said that the fundamental significance of economic integration is the increase of actual or potential competition. Furthermore, competition by market participants is likely to lead to lower prices for similar goods and services, to greater quality variation and wider choice for the integrating area, as well as to a general impetus for change. Product designs, services methods, production and distribution systems and any other aspects become subject to actual and potential challenge. They may induce changes in the direction and intensity of innovation and in working habits.

Proposed by El-Agraa (1997), there are different forms of integration but the essence of the integration arrangement is the discriminatory removal of all trade obstacles between at least two participating nations and the promotion of some form of cooperation and coordination between the participating countries. The table 1 below exhibits the stages regarding El-Agraa:

\begin{tabular}{l|c|c|c|c|c}
\multicolumn{7}{c}{ The Features of International Economic Integration } \\
\multicolumn{1}{c|}{ Type } & Free Trade Area & $\begin{array}{c}\text { Customs } \\
\text { Union }\end{array}$ & $\begin{array}{c}\text { Common } \\
\text { Market }\end{array}$ & $\begin{array}{c}\text { Economic } \\
\text { Union }\end{array}$ & $\begin{array}{c}\text { Total Political } \\
\text { Union }\end{array}$ \\
\hline Policy Action & & $\sqrt{ }$ & $\sqrt{ }$ & $\sqrt{ }$ \\
\hline $\begin{array}{l}\text { Removal of tariffs and } \\
\text { quotas }\end{array}$ & $\sqrt{ }$ & $\sqrt{ }$ & $\sqrt{ }$ & $\sqrt{ }$ \\
\hline Common external tariff & & $\sqrt{ }$ & $\sqrt{ }$ & $\sqrt{ }$ \\
\hline Factor mobility & & & $\sqrt{ }$ & $\sqrt{ }$ \\
\hline $\begin{array}{l}\text { Harmonization of } \\
\text { economic policies }\end{array}$ & & & & & \\
\hline $\begin{array}{l}\text { Total unification of } \\
\text { economic policies } \\
\text { Source: El-Agraa, (1997) }\end{array}$ & & & & & \\
\hline
\end{tabular}

Furthermore, in free trade areas the member countries remove all trade impediments among themselves but each country retains the right to determine their policies in relation to non-participating countries. The agreement usually includes the elimination of tariffs and quantitative restrictions on trade. The rules of origin are the basis of the agreement. The rules 
of origin imply that only those commodities that originate from a member state are granted from tariff. The examples of free trade areas include the European Free Trade Association (EFTA), comprising of the UK, Austria, Denmark, Norway, Portugal, Sweden, Switzerland and Finland and the North American Free Trade Area (NAFTA) formed in 1993 by the United States, Canada and Mexico. Then, in customs unions, member countries, as in free trade areas, remove all trade impediments among the participating countries.

Thus, the member countries harmonize their trade policies and, in particular, have common external tariffs on imports from non-participating countries. The most well known customs union is the European Common Market formed in 1957 by West Germany, France, Italy, Belgium, the Netherlands and Luxembourg. The item of common markets are customs unions with the added feature that there is free mobility of factors of production i.e. labor, capital, enterprises and technology, across the participating countries.

In 1992 the European Union (EU) achieved the status of a common market.Economic unions are common markets where there is unification of monetary and fiscal polices. Monetary policy is managed by a central bank. The union will have a single currency, in the case of the European Union, the euro. There is a central authority to exercise control over these matters. This is considered to be the most advanced form of economic integration. Finally, the total political union can be defined as the participating countries become one nation. The central economic authority is supplemented by a common parliament and other institutions. As the highest stage, the total political union had been already implemented by European Union.

In addition, Balassa (1961) introduced theprominent crucial stages to aim the economic integration. These stages can be expressed as table 2 below:

\begin{tabular}{|c|c|}
\hline \multicolumn{2}{|c|}{$\begin{array}{l}\text { Table } 2 . \\
\text { Balassa'sCrucial Stages on Economic Integration }\end{array}$} \\
\hline Stage & Brief Definition \\
\hline $\begin{array}{l}\text { Stage } 1 \\
\text { Free Trade Area (FTA) }\end{array}$ & $\begin{array}{l}\text { - Tariffs and quotas abolished for imports from area members } \\
\text { - } \quad \text { Area members retain national tariffs (and quotas) against third countries }\end{array}$ \\
\hline $\begin{array}{l}\text { Stage } 2 \\
\text { Customs union (CU) }\end{array}$ & $\begin{array}{l}\text { - Suppressing discrimination for CU members in product markets } \\
\text { - Equalization of tariffs (and no, or common, quotas) in trade with non- } \\
\text { members }\end{array}$ \\
\hline $\begin{array}{l}\text { Stage } 3 \\
\text { Common Market (CM) }\end{array}$ & - A CU which also abolishes restrictions on factor movements \\
\hline $\begin{array}{l}\text { Stage } 4 \\
\text { Economic Union }\end{array}$ & $\begin{array}{l}\text { - A CM with some degree of harmonization of national economic policies } \\
\text { in order to remove discrimination due to disparities in these policies }\end{array}$ \\
\hline $\begin{array}{l}\text { Stage } 5 \\
\text { Total Economic Integration }\end{array}$ & $\begin{array}{l}\text { - Unification of monetary, fiscal, social and counter cyclical policies } \\
\text { - Setting up of a supranational authority where decisions are binding } \\
\text { for the member states }\end{array}$ \\
\hline
\end{tabular}


The crucial stages are presented sequentially for analytical reasons. However, there is no mandatory to follow the Balassa's crucial stages. The European Economic Community (EEC) launched a customs union (CU), not free trade areas (FTAs). In contrast NAFTA started with strategy of free trade areas (FTAs). Balassa's crucial stages of economic integration provide the systematic of concept in order to attain the real economic integration.

\section{Fundamental Theory of Trade Integration}

International trade in goods and services takes place because countries have different resource endowments and labor skills and because consumer tastes vary from country to country. David Ricardo, a $19^{\text {th }}$-century British Economist, argued that a country could gain from trade even when another country had an absolute advantage in producing all goods and services. Ricardo's approach is based on the hypothesis of international capital immobility. He argued, rightly, that by concentrating on producing those goods and services in which a country was relatively more efficient and importing those products in which it was relatively less efficient, it could increase its national income. And this would be so even if that country was absolutely less efficient in producing all products. In other words, international capital immobility leads to specialization in terms of comparative advantage.

Dodge (2003) said that so when countries export goods and services in which they are less competitive, consumers everywhere benefit, the potential output of all nations increases, and so does the global standard of living. In the end, competitive pressure leads to greater efficiency, greater productivity, and higher standard of living. Another side, free trade needs adjustment costs to be borne as barriers to trade removed. This is part of the process of releasing resource both human and physical to those industries or firms that are taking advantage of new markets abroad. The partial conclude is some kind of mechanism to equitably share the short run costs of adjustment is important to reap the medium and longer run benefits of free trade.

Pelkmans (2006) believes that trade integration is a behavioral notion indicating that activities of market participants in different regions or member states are geared to supply and demand conditions in the entire union (or other relevant area). Usually, this will also show up in significant cross frontier movements of goods, services and factors.

\section{Discrepancy between Free Trade Areas (FTA) and Customs Union (CU)}

With respect to FTA and CU, Husted and Melvin (2010) explained that basic difference between FTA and $\mathrm{CU}$ is how the member countries treat non-member countries. By definition of them, FTAs is an agreement among several countries to eliminate internal barriers to trade but to maintain existing barriers against non-member countries and $\mathrm{CU}$ is an agreement among several countries to eliminate internal barriers to trade and to erect common barriers against 
nonmember countries. Tariffs are linked to eliminate internal barriers named it as preferential trade arrangements (PTAs). The terminology of PTAs is preferential (or discriminatory) trade arrangements that various countries have agreed to reduce even further barriers to trade among themselves.

PTAs in another side are surely involving and affecting three agents of economics in the FTAs or CU countries (Husted and Melvin, 2010): first, consumer, that would be consumer surplus or loss depend on export side or import side. Consumer surplus is the difference between the amount consumers are willing to pay to purchase a given quantity of goods and the amount they have to pay to purchase those goods or vice versa if consumer loss. Second, producer, that would be producer surplus or loss depend on as export side or import side. Producer surplus is the difference between the price paid in the market for a good and the minimum price required by an industry to produce and market that good or vice versa if producer loss. Third, government enjoys the decreasing of tariff revenue.

Husted and Melvin (2010) in expressively also said that PTAs have two primary economic implications: first, trade diversion is a shift in the pattern of trade from low cost world producers (natural comparative advantage) to higher cost CU or FTAs members. The consequences of trade diversion are in the process, the resources are directed away from merchandise or commodity in the low cost (natural comparative advantage) world producers and directed toward merchandise or commodity production in the higher cost partner country (FTAs or CU members) that effect to consumer loss, producer surplus, and the tariff revenue of government absolutely will fall. Second, trade creation is an expansion in world trade that results from the formation of PTAs. The consequence is the replacement of higher cost domestic production of import goods by lower cost imports that effect to consumer surplus, producer loss, and tariff revenue falls.

The optimum strategy related those two economic implications of PTAs is maximize trade creation and minimize trade diversion will give beneficial to FTAs or CU welfare effect. Besides affecting agents and have economic implication, PTAs in free trade (FTAs or CU) have gains from point of view import side and from point of view export side (Husted and Melvin, 2010): first, From the point of view of the importer country, PTAs in free trade (FTAs or CU) will gain for consumers and domestic producers are worse; because of consumers are able to purchase this product at a lower price and the lower price leads some producers to reduce the quantity supplied and others to drop out of the market. Second, from the perspective of an exporter country, PTAs in free trade (FTA or CU) will gain for producers and consumer loss; because of domestic producers would expand output in response to the higher price from partner FTA or CU members and the higher price leads some consumers demand will fall. 


\section{Gravity Equation Model}

The Gravity Equation model has been to be recognized model that already applied to in varying disciplines and sectors like migration, foreign direct investment, and more specifically to international trade flows and also becoming robust tool to analyze foreign trade or free trade analysis phenomena. The basic Gravity Equation Model or Gravity model can be written as:

$$
T_{i j}=A \times Y_{i}^{a} \times Y^{b} / D_{i j}^{c}
$$

$T_{i j}$ is the value of trade between country $i$ and country $j, Y_{i}$ is country i's GDP, $Y_{j}$ is countryj's GDP, and $D_{i j}$ is the distance between the two countries. This general Gravity Equation model is cited from Krugman and Obstfeld (2009). They also stated that the reason for the name is the analogy to Newton's law of gravity: Just as the gravitational attraction between any two objects is proportional to the product of their masses and diminishes with distance, the trade between any two countries is, other things equal, proportional to the product of their GDPs and diminishes with distance.

Moreover, there are three valuable statements from Krugman and Obstfeld (2009) in discussing about the Gravity model: first, in relation with 'the size matters of Gravity Model': There is a strong empirical relationship between the size of a country economy and the volume both its imports and its exports. Second, in relation with 'the logic of the Gravity Model': Why does the gravity model work? Broadly speaking, large economies tend to spend large amounts on imports because they have large incomes. They also tend to attract large shares of other countries' spending because they produce a wide range of products.

So the trade between any two economies is larger. Third, in relation with the looking for anomalies using the Gravity Model: In fact, one of the principal uses of gravity models is that they help us to identify anomalies in trade. Indeed, when trade between two countries is either much more or much less than a gravity model predicts, economist search for the explanation.

However, some studies derived the basic gravity equation model into a modified formation depend upon the specification either concerning to bilateral or regional free trade. The table 3expressed such a modified gravity equation model: 


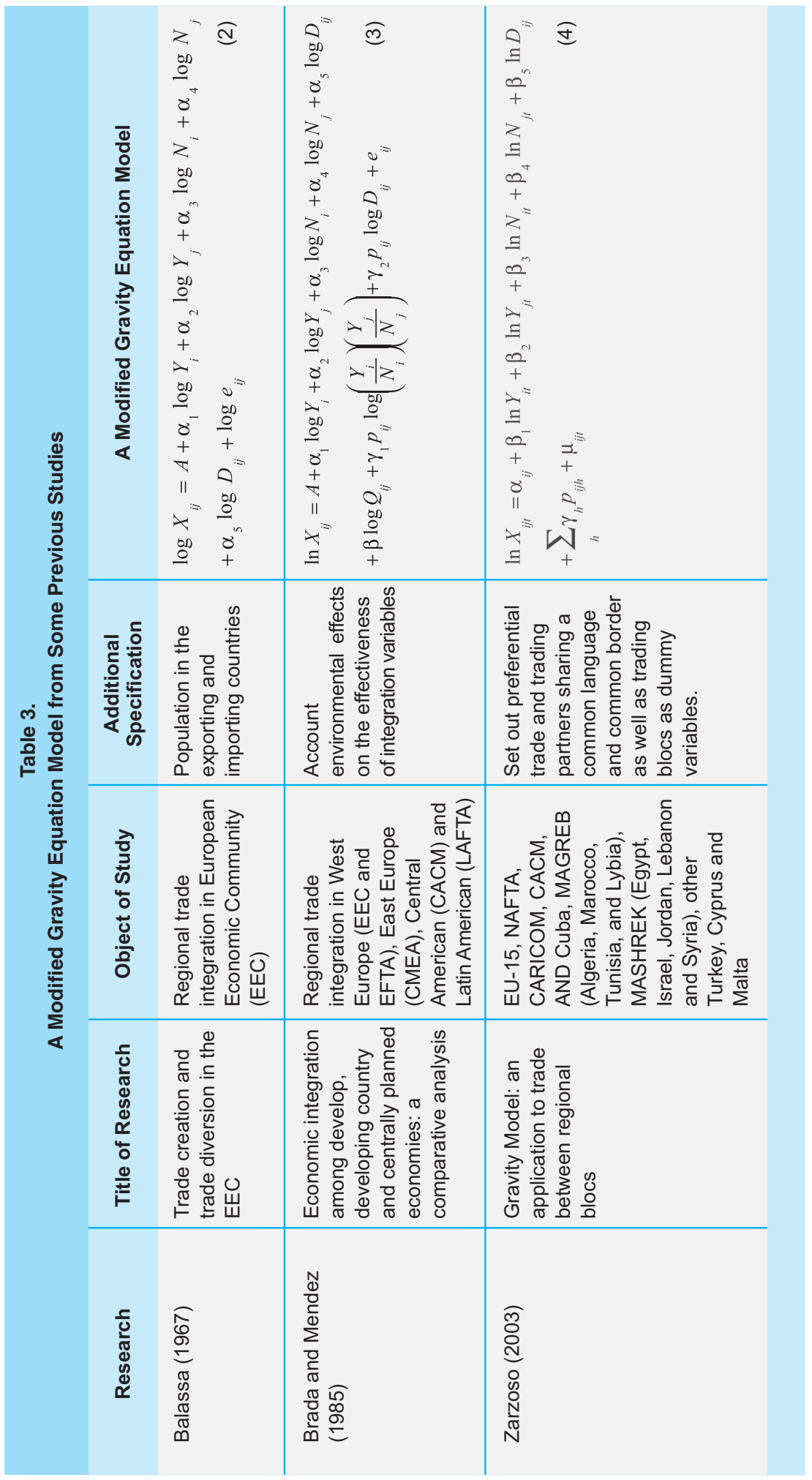


The effect of the existence of some modified gravity equation models from previous stand point allows rich analysis due to the dynamics of trade. This table below describes the interpretation directly to coefficients of the modified model:

\begin{tabular}{|c|c|}
\hline \multicolumn{2}{|c|}{$\begin{array}{l}\text { Table } 4 . \\
\text { Parameters Interpretation According to Previous Studies }\end{array}$} \\
\hline Empirical Study & The Parameters Interpretation \\
\hline Calvo-Pardo, et.al (2009) & $\begin{array}{l}\text { - If the coefficient of preferential tariffs is negative, therefore the cost of } \\
\text { import is greater than others and vice versa }\end{array}$ \\
\hline Pacheco and Pierola (2008) & $\begin{array}{l}\text { - Expected the real GDP or GDP per capita and the distance to show positive } \\
\text { and negative coefficient sign respectively } \\
\text { - The results obtained for the gravity variables reflect that the larger the size } \\
\text { of the market at destination and the closer the markets (lower trade costs), } \\
\text { the larger the increase in the volume of exports }\end{array}$ \\
\hline Zarzoso (2003) & $\begin{array}{l}\text { - A high level of income in the exporting country indicates a high level of } \\
\text { production, which increases the availability of goods for export. Therefore } \\
\text { the coefficient is expected to be positive } \\
\text { - A high level income in the importing country suggests higher imports. So } \\
\text { the coefficient of it expected to be positive too } \\
\text { - The coefficient estimate for population of the exporters may be negatively } \\
\text { or positively signed, depending on whether the country exports less } \\
\text { (absorption effect) or whether a big country exports more than a small } \\
\text { country (economies of scale) } \\
\text { - The coefficient of the importer population, also has an ambiguous sign, } \\
\text { for similar reasons } \\
\text { - The distance coefficient is expected to be negative since it is a proxy of } \\
\text { all possible trade costs }\end{array}$ \\
\hline Tamirisa (1999) & $\begin{array}{l}\text { - Distance has a significant negative effect on bilateral exports, in part } \\
\text { because trade costs (like transportation and communication) are likely to } \\
\text { increase with distance } \\
\text { - Tariff barriers in the importing countries also tend to have a negative, } \\
\text { insignificant, effect on exports into these countries } \\
\text { - GDP and population, on the other hand, have significant positive effects } \\
\text { on bilateral exports }\end{array}$ \\
\hline Brada and Mendez (1985) & $\begin{array}{l}\text { - The income and population variables represent the trading countries } \\
\text { endowments and tastes. Since greater productivity capacity and income } \\
\text { promote trade, all coefficients are expected to be positive } \\
\text { - Large countries have more diversified production and thus satisfy a greater } \\
\text { proportion of domestic demand while small countries tend to be more } \\
\text { specialized and thus more dependent on trade, suggesting that coefficient } \\
\text { of it should be negative } \\
\text { - The population of the importing country should have a positive effect on } \\
\text { the volume of trade, since a larger population permits a greater division } \\
\text { of labor and diversity of production, enabling imports to compete with } \\
\text { domestic goods at more stages of the production process. Moreover, a } \\
\text { large market better compensates exporters for the cost of acquiring } \\
\text { information and establishing a sales and distribution network. Thus coefficient } \\
\text { of it should be positive }\end{array}$ \\
\hline
\end{tabular}




\section{METHODOLOGY}

This paper proposed a Modified Gravity Equation model such following equation:

$\log \sum$ TBRubber $_{i j}=\alpha_{1}+\alpha_{2} \log Y_{i}+\alpha_{3} \log Y_{j}+\alpha_{4} \log D_{i j}+\alpha_{5} \log t_{i}$

$+\alpha_{6} \log t_{j}+\alpha_{7} \log e x_{i}+\alpha_{8} \log e x_{j}+\log e_{i j}$

$\log \sum$ TBWood $_{i j}=\alpha_{1}+\alpha_{2} \log Y_{i}+\alpha_{3} \log Y_{j}+\alpha_{4} \log D_{i j}+\alpha_{5} \log t_{i}$

$+\alpha_{6} \log t_{j}+\alpha_{7} \log e x_{i}+\alpha_{8} \log e x_{j}+\log e_{i j}$

$\log \sum$ TBAgro $_{i j}=\alpha_{1}+\alpha_{2} \log Y_{i}+\alpha_{3} \log Y_{j}+\alpha_{4} \log D_{i j}+\alpha_{5} \log t_{i}$

$+\alpha_{6} \log t_{j}+\alpha_{7} \log e x_{i}+\alpha_{8} \log e x_{j}+\log e_{i j}$

$\log \sum$ TBFisheris ij $_{i j}=\alpha_{1}+\alpha_{2} \log Y_{i}+\alpha_{3} \log Y_{j}+\alpha_{4} \log D_{i j}+\alpha_{5} \log t_{i}$

$+\alpha_{6} \log t_{j}+\alpha_{7} \log e x_{i}+\alpha_{8} \log e x_{j}+\log e_{i j}$

Where

- $\quad \Sigma_{T B_{i j}}$ is sum value of trade balance (net exports) of rubber based-products, wood basedproducts, agro based-products, and fisheries from Indonesia (i) to other selected ASEAN members (j) in US Dollar;

- $\alpha_{1}$ is constant or unobserved effect;

- $\quad Y_{i t}, Y_{j t}$ are GDP per capita of Indonesia and other selected ASEAN members GDP per capita in US Dollar

- $\quad D_{i j}$ is distance between Indonesia capital city (i) and other selected ASEAN members capital city (j) kilometer;

- $t_{i}$ is Indonesia average CEPT rates (i) in percentage;

- $\quad t_{j}$ is selected ASEAN members average CEPT rates (j) in percentage;

- $\quad e x_{i}$ is Indonesia real exchange rates (i) in per US Dollar;

- $\quad e x_{j}$ is selected ASEAN members average CEPT rates (j) in per US Dollar;

- $e_{i j}$ is lognormal error term. 
The data of the examination retrieved from International Trade Centre ${ }^{2}$ that containing the data of trade balances. Then, data of the GDP per capita plus the CEPT, the distance, and real exchange rates are compiled from ASEAN and other sources ${ }^{3}$, and International Financial Statistic 2009, respectively. The time period all of the data are from 2002 to 2008.

This paper estimates and giving an analysis tothe importance of the coefficient magnitude. First, a high level of income in the exporting country indicates a high level of production. Thus, it increases the abundant ofgoods to export. The notion of $\alpha_{2}$ denotes to bepositive ( + ) and might be interpreting as whether the absorption effect or the role of play within the free trade zone. Second, the notation of $\alpha_{3}$ is also expected to be positive (+) since a high level income in the importing country suggests higher imports and also connected to the four primary option i.e. the absorption effect orthe scale of economies orthe natural comparative advantage, and or the role of play. Third, the distance parameters of $\alpha_{4}$ is a positive $(+)$ since it is a proxy of all possible trade costs and also positive related to efficient trade costs. Distance has a significant negative effect on bilateral exports, in part because trade costs (such transportation and communication) are likely to increase with distance or vice versa.

Fourth, the notation of $\alpha_{5}$ occurs as a positive $(+)$ sign in which Indonesia induces lowering the cost of import (ACEPT rate) instead of selected members. In this context, Indonesia can be defined as an importer and therefore can be associated with a trade creation strategy. A trade creation policy signifies to gain much beneficial from free trade. Fifth, the coefficient of $\alpha_{6}$ notes to possess negative (+) sign and hence, the Indonesia cost of export (ACEPT rate) can be lower compared to selected members. Thus, it can be inferred that Indonesia allows to strategy of a trade creation. Sixth, it is expected that the notion of $\alpha_{7}$ denotes negative (-) sign and however for the parameter of $\alpha_{8}$ is estimated to be positive $(+)$. Both of which indicates that Indonesia Rupiah (IDR) undervalued over selected members currency. As a consequence, Indonesia trade balance increases constructively because its products are definitely cheaper than other competitor products.

Furthermore, this paper will utilize Pooled Least Square (PLS) method therefore panel data or pooled data within pooling in time series and cross-sectional observations or combination of time series and cross-section data (Gujarati and Porter, 2009). Then Gujarati and Porter (2009) elaborate the advantages of panel data over just cross section or just time series data: first, by combining time series of cross section observations, panel data gives more informative data, more variability, less collinearity among variables, more degrees of freedom and more efficiency. Second, by studying the repeated cross section of observations, panel data are better suited to study the dynamic of change. Third, panel data can better detect and measure effects that simply cannot be observed in pure cross section or pure time series data. Fourth, panel data enables us to study more complicated behavioral models.

2 Downloadable at www.trademap.org.

3 Available at www.asean.org, www.indo.com/distance and www.geobytes.com/citydistancetool.htm. 
Pooled Least Square (PLS) regression or Constant Coefficients Model is assumed that explanatory variables (independent variables) are non stochastic. If they are stochastic, they are uncorrelated with the error term. Sometimes it is assumed that the explanatory variables are 'strictly exogenous. A variable is said to be strictly exogenous if it does not depend on current, past, and future values of the error term (Gujarati and Porter, 2009). It is also assumed that the error term is $e_{i j} \sim$ idd $\left(0, \sigma^{2}\right)$ that is, it is independently and identically distributed with zero mean and constant variance and also may be assumed that error term is normally distributed.

The outcomes of PLS will provide two estimations as a baseline to analyze Indonesian multilateral trading counterparty: first, prob. (t-stat) or t test or testing hypothesis about any individual partial regression coefficient, particularly for explanatory variables towards dependent variables. Linkage to the hypothesis testing, this paper employs if the $\rho$-value or prob. (t-stat) is less thanany level of significance $\alpha$ at $1 \%, 5 \%$, or $10 \%$, automatically the null hypothesis is rejected. It implies the independent variables are partially affectedby the dependent variables (Gujarati and Porter, 2009). These estimations have a function to make prominent interpretation of each parameter related to reveal trade pattern.

Second, the adjusted $R^{2}$, is a descriptive measure of the strength of the regression relationship, a measure of how well the regression line fits the data (Aczel, 1995). Moreover, Aczelmentions that the requirement of an indication of the relative fit of the regression model to the data such $R^{2}$ value of 0.9 or above is very good, a value above 0.8 is good, a value of 0.6 or above may be satisfactory, a value of 0.5 or below maybe poor. However, referring to Aczel, this paper proposes different criteria due to utilization of the adjusted $R^{2}$. The interval valueof the adjusted $R^{2}$ ranges from $0 \%$ to $25 \%$; $26 \%$ up to $50 \%$; and $51 \%$ to $100 \%$ imply as a poor sector of Indonesia, as a weak sector for Indonesia and as a strength sector for Indonesia respectively. 


\section{RESULT AND ANALYSIS}

This table below shows the regressed of a modified gravity equation model:

\begin{tabular}{|c|c|c|c|c|c|}
\hline \multicolumn{6}{|c|}{$\begin{array}{l}\text { Table } 5 . \\
\text { A Modified Gravity Equation Estimated for Rubber Based-Products sector }\end{array}$} \\
\hline Indonesia to: & Brunei & Malaysia & Philippines & Singapore & Thailand \\
\hline Constanta & $\begin{array}{c}69.54481^{*} \\
(0.0000)\end{array}$ & $\begin{array}{c}62.08589^{*} \\
(0.0000)\end{array}$ & $\begin{array}{c}89.70640^{*} \\
(0.0000)\end{array}$ & $\begin{array}{c}80.91527^{*} \\
(0.0000)\end{array}$ & $\begin{array}{l}26.31651^{* * *} \\
(0.0351)\end{array}$ \\
\hline$Y_{i}$ & $\begin{array}{l}-3.311988 \\
(0.1351)\end{array}$ & $\begin{array}{r}2.923614 \\
(0.3621)\end{array}$ & $\begin{array}{c}-2.025016^{*} \\
(0.0016)\end{array}$ & $\begin{array}{l}-2.231605^{*} \\
(0.0006)\end{array}$ & $\begin{array}{c}-2.091311^{*} \\
(0.0000)\end{array}$ \\
\hline$Y_{j}$ & $\begin{array}{c}-0.930077 \\
(0.6104)\end{array}$ & $\begin{array}{l}-6.063400^{* * *} \\
(0.0819)\end{array}$ & $\begin{array}{l}-3.397438^{*} \\
(0.0002)\end{array}$ & $\begin{array}{l}-3.193488^{*} \\
(0.0003)\end{array}$ & $\begin{array}{l}-1.281840^{* * *} \\
(0.0513)\end{array}$ \\
\hline$D_{i j}$ & $\begin{array}{c}-14.62007^{*} \\
(0.0002)\end{array}$ & $\begin{array}{c}-13.63169^{*} \\
(0.0001)\end{array}$ & $\begin{array}{c}-19.46577^{*} \\
(0.0000)\end{array}$ & $\begin{array}{c}-16.82774^{*} \\
(0.0001)\end{array}$ & $\begin{array}{c}-2.370968 \\
(0.4434)\end{array}$ \\
\hline$t_{i}$ & $\begin{array}{c}-3.79719^{* *} \\
(0.0203)\end{array}$ & $\begin{array}{c}-0.569571 \\
(0.7713) \\
\end{array}$ & $\begin{array}{c}-0.901370 \\
(0.5606)\end{array}$ & $\begin{array}{c}-1.289047 \\
(0.3631) \\
\end{array}$ & $\begin{array}{c}1.704444^{* * *} \\
(0.0701) \\
\end{array}$ \\
\hline$t_{j}$ & $\begin{array}{c}-0.038478 \\
(0.9635)\end{array}$ & $\begin{array}{c}-0.542890 \\
(0.7818)\end{array}$ & $\begin{array}{c}-1.118072 \\
(0.4741)\end{array}$ & $\begin{array}{c}-0.903995 \\
(0.5320)\end{array}$ & $\begin{array}{c}-3.094332 \\
(0.0007)\end{array}$ \\
\hline$e x_{i}$ & $\begin{array}{l}0.307146 \\
(0.7252)\end{array}$ & $\begin{array}{c}-0.677290 \\
(0.4547)\end{array}$ & $\begin{array}{c}1.081600^{*} \\
(0.0006)\end{array}$ & $\begin{array}{c}0.887683^{* *} \\
(0.0123)\end{array}$ & $\begin{array}{c}-0.089683 \\
(0.7138)\end{array}$ \\
\hline$e x_{j}$ & $\begin{array}{c}-0.015210 \\
(0.9888)\end{array}$ & $\begin{array}{l}1.261404 \\
(0.2777)\end{array}$ & $\begin{array}{c}-0.360184 \\
(0.2795)\end{array}$ & $\begin{array}{c}-0.170639 \\
(0.6583)\end{array}$ & $\begin{array}{c}0.836867^{*} \\
(0.0026)\end{array}$ \\
\hline N. Adj. $R^{2}$ & $\begin{array}{c}63 \\
0.318435\end{array}$ & $\begin{array}{c}63 \\
0.248718\end{array}$ & $\begin{array}{c}63 \\
0.433426\end{array}$ & $\begin{array}{c}63 \\
0.446564\end{array}$ & $\begin{array}{c}63 \\
0.726532\end{array}$ \\
\hline
\end{tabular}

The given information from table 5 describesthe significant estimation of the coefficient of the Indonesia GDP per capita towardsPhilippines, Singapore and Thailand. Yet, the coefficient of Indonesia GDP per capita is not sufficiently enough to point out the examination of the dynamics trade flow between Indonesia and the countries mentioned previous. Thereby, the GDP per capita from side of Philippines, Singapore and Thailand is taking into account. The GDP per capita of Philippines, Singapore and Thailand are noticeable the magnitude as well. Nonetheless, the marking of the estimation all of these countries are counter with Indonesia. Therefore, the difference makes out the implication. Consequently, Indonesia might be majorly importing the final rubber based-productsparticularly from Singapore and Thailand like tire for automotive. And as trade off, Indonesia rubber based-productsmight be extensively exported in favor of raw, intermediated and final goods as well to Singapore, Thailand and Philippines.

Then, the signifying of the notion of distance is attributed to Brunei, Malaysia, Singapore and Thailand. However, these countries possessnegative estimation and it associated to the increasing of trading expenses such transportation, communication and administration. In the applied, suppose Indonesia producers spill rubber based-products to Brunei. Prior to the deal of 
trade, Indonesia producers will take place $14.6 \%$ from the overall transaction as the trade expenses. This paper found that the most costly of trading goes to Philippines by $19.5 \%$.

The estimation of notation $t_{i}$ and $t_{j}$ explore the tariff ACEPT exercising. The significance ACEPT is featuring between Indonesia and Thailand. However, this featuring only focuses to Indonesia ACEPT which is lowering $1.7 \%$ than Thailand. The information of previous deduces that Indonesia as an importer country may allow to implement a trade creation strategy. This strategy imposes the beneficial for Indonesian consumer therefore enjoying the importing rubber based-products due to relative cheaper price tag rather domestic rubber based-products. Thus, yet, Indonesia producers are loss by $1.7 \%$ in response to imported finished goods. The advantageous only occur once Indonesian producers are taking crude and intermediated goods into account of import. By that implementation, Indonesian producers can be saving the money up to $1.7 \%$. In contrast, Indonesia government as the third party definitely possesses the falling tariff revenue about $1.7 \%$.

The estimation of the notation Thailand Bath (THB) implies the magnitude and in contrast with the Indonesia Rupiah (IDR). Consequently, if the THB is appreciating over IDR by then it might be elevating the Indonesia net export to around $0.83 \%$ or vice versa. Furthermore, the important information is containing within the table 5 is the estimation of theadjusted $R^{2}$ in which reflecting the grading of rubber based-products sector comparing Indonesia to selected ASEAN members. This paper found that Indonesia incurs rubber based-products as a strength commodity to trade with Thailand $(72.65 \%)$. Nevertheless, the rest indicates not strategically to make significant trade therefore the weak and the poor estimation of adjusted $R^{2}$.

The following table 6 depicts two effects regarding the GDP per capita estimation. First, the significance estimation and the positive sign of Indonesian GDP per capita indicate that Indonesia directly exports magnitude wood based-products to Brunei. Second, in the similar significance but with the negative sign of Indonesian GDP per capita assures that Indonesia allow to open import of rubber based-products from Malaysia, Philippines, Singapore, and Thailand.It is a plausible finding that Indonesia is not strictly riveted to push its export to these countries. As a suggestion that it might explicable that importing from these countries is only beneficial forthe wood based-products in form of whether of crude or intermediated goods in order to process of each or both to be an added value rubber based-products. Later on, the added value goods can be spilled out to the non-member of AFTA such Europe, USA, Japan, India and China. The strategy of this is useful to lift much more trade surplus. Concerning to the trade cost by the parameter of distance, it reveals that the highest trade cost places to Philippines because of taking about $14.3 \%$ into expenses from the total deal of transaction.

In the case of the cost of import, Indonesia versus Malaysia has the same significance estimation. The table 6 exhibits that Malaysia actuallyimposes highercost of import (ACEPT) compared to Indonesia. By this condition, Indonesia may apply the strategy of trade diversion or trade creation. To address the trade diversion, Indonesia is acted as an exporter. Consequently, 


\begin{tabular}{|c|c|c|c|c|c|}
\hline \multicolumn{6}{|c|}{$\begin{array}{l}\text { Table } 6 . \\
\text { A Modified Gravity Equation Estimated for Wood Based-Products Sector }\end{array}$} \\
\hline Indonesia to: & Brunei & Malaysia & Philippines & Singapore & Thailand \\
\hline Constanta & $\begin{array}{l}-27.90990 \\
(0.1132)\end{array}$ & $\begin{array}{c}59.66644^{*} \\
(0.0000)\end{array}$ & $\begin{array}{c}58.21403^{*} \\
(0.0001)\end{array}$ & $\begin{array}{l}41.79043^{* *} \\
(0.0136)\end{array}$ & $\begin{array}{c}48.18736^{* *} \\
(0.0174)\end{array}$ \\
\hline$Y_{i}$ & $\begin{array}{c}9.186632^{*} \\
(0.0008)\end{array}$ & $\begin{array}{l}-7.485078^{*} \\
(0.0000)\end{array}$ & $\begin{array}{l}-2.841708^{*} \\
(0.0000)\end{array}$ & $\begin{array}{l}-2.559711^{*} \\
(0.0004)\end{array}$ & $\begin{array}{c}-2.660826^{*} \\
(0.0002)\end{array}$ \\
\hline$Y_{j}$ & $\begin{array}{l}-4.0585^{* * *} \\
(0.0622)\end{array}$ & $\begin{array}{c}3.076818^{*} \\
(0.0005)\end{array}$ & $\begin{array}{l}1.225369 \\
(0.1435)\end{array}$ & $\begin{array}{l}1.517875 \\
(0.1032)\end{array}$ & $\begin{array}{l}1.739184^{* * *} \\
(0.0989)\end{array}$ \\
\hline$D_{i j}$ & $\begin{array}{l}4.223679 \\
(0.3270)\end{array}$ & $\begin{array}{l}-10.88413^{*} \\
(0.0004)\end{array}$ & $\begin{array}{l}-14.43766^{*} \\
(0.0000)\end{array}$ & $\begin{array}{l}-10.18010^{* *} \\
(0.0195)\end{array}$ & $\begin{array}{c}-12.22422^{\star *} \\
(0.0170)\end{array}$ \\
\hline$t_{i}$ & $\begin{array}{c}4.121848^{* *} \\
(0.0310)\end{array}$ & $\begin{array}{c}2.895193^{* *} \\
(0.0649)\end{array}$ & $\begin{array}{c}2.971138^{* * *} \\
(0.0569)\end{array}$ & $\begin{array}{l}1.410275 \\
(0.3687)\end{array}$ & $\begin{array}{c}-0.389457 \\
(0.7940)\end{array}$ \\
\hline$t_{j}$ & $\begin{array}{l}0.039465 \\
(0.9681)\end{array}$ & $\begin{array}{c}-2.837597^{\star * *} \\
(0.0729)\end{array}$ & $\begin{array}{c}-2.495213 \\
(0.1105)\end{array}$ & $\begin{array}{c}-0.992821 \\
(0.5352)\end{array}$ & $\begin{array}{c}0.916415 \\
(0.5093)\end{array}$ \\
\hline$e x_{i}$ & $\begin{array}{c}-2.967334^{*} \\
(0.0054)\end{array}$ & $\begin{array}{c}3.310880^{*} \\
(0.0000)\end{array}$ & $\begin{array}{l}1.622403^{*} \\
(0.0000)\end{array}$ & $\begin{array}{l}1.359832^{*} \\
(0.0008)\end{array}$ & $\begin{array}{c}1.582950^{*} \\
(0.0002)\end{array}$ \\
\hline$e x_{j}$ & $\begin{array}{c}3.284086^{* *} \\
(0.0122)\end{array}$ & $\begin{array}{c}-1.574310^{*} \\
(0.0000)\end{array}$ & $\begin{array}{c}-1.124434^{*} \\
(0.0012)\end{array}$ & $\begin{array}{c}-1.003077^{\text {** }} \\
(0.0222)\end{array}$ & $\begin{array}{c}-1.267789^{*} \\
(0.0044)\end{array}$ \\
\hline N. Adj. $R^{2}$ & $\begin{array}{c}63 \\
0.442858\end{array}$ & $\begin{array}{c}63 \\
0.677137\end{array}$ & $\begin{array}{c}63 \\
0.669456\end{array}$ & $\begin{array}{c}63 \\
0.596437\end{array}$ & $\begin{array}{c}63 \\
0.577371\end{array}$ \\
\hline
\end{tabular}

Indonesia producers are relatively loss on exporting to Malaysia by $2.84 \%$ therefore facing ahigher tariff. In response to this, Malaysia producers may increase their price the same as the wood based-products from Indonesia. And the surplus is gained by Malaysia worth $2.84 \%$. Nevertheless, the Malaysia consumers indicate loss up to $2.8 \%$ and in oppose with the government where enjoying the tariff revenues to around $2.8 \%$.

How about the Indonesiaasimporter in this case? Automatically it mainly applies the trade creation. The effects of a trade creation are smoothly advantageous for Indonesia consumersnot to mention Indonesia producers. Indonesia consumers relatively satisfied to consume cheap wood based-products from Malaysia. Indonesia producers in related to further processing will accept discount to around $2.9 \%$ by importing in form of raw materials and semi finished-goods. If the exchange rate of IDR is defined appreciating against Philippines Peso (PHP) therefore it might potentially underminethe value of the Indonesia net export in terms of the wood based-products to approximate $0.5 \%$. The estimation of adjusted $R^{2}$ identifies Malaysia (67.7\%), Philippines (66.95), Singapore (around 60\%) and Thailand (57.7\%) as the importance partners for the Indonesia trade flows under the scheme of AFTA. It implies these countries possibly generate high volume of trading with Indonesia regarding the wood basedproducts. 


\begin{tabular}{|c|c|c|c|c|c|}
\hline \multicolumn{6}{|c|}{$\begin{array}{l}\text { Table } 7 . \\
\text { A Modified Gravity Equation Estimated for Agro Based-Products sector }\end{array}$} \\
\hline Indonesia to: & Brunei & Malaysia & Philippines & Singapore & Thailand \\
\hline Constanta & $\begin{array}{l}52.05350^{*} \\
(0.0011)\end{array}$ & $\begin{array}{c}67.35654^{*} \\
(0.0000)\end{array}$ & $\begin{array}{c}120.2942^{*} \\
(0.0000)\end{array}$ & $\begin{array}{c}108.5072^{*} \\
(0.0000)\end{array}$ & $\begin{array}{c}67.39194^{*} \\
(0.0000)\end{array}$ \\
\hline$Y_{i}$ & $\begin{array}{l}4.83860^{* * *} \\
(0.0334)\end{array}$ & $\begin{array}{l}-10.05339^{*} \\
(0.0038)\end{array}$ & $\begin{array}{l}-3.283774^{*} \\
(0.0000)\end{array}$ & $\begin{array}{l}-3.103830^{*} \\
(0.0000)\end{array}$ & $\begin{array}{l}-2.923801^{*} \\
(0.0000)\end{array}$ \\
\hline$Y_{j}$ & $\begin{array}{l}-8.376061^{*} \\
(0.0000)\end{array}$ & $\begin{array}{l}6.477341^{* * *} \\
(0.0740)\end{array}$ & $\begin{array}{l}-4.634652^{*} \\
(0.0000)\end{array}$ & $\begin{array}{l}-4.427253^{*} \\
(0.0000)\end{array}$ & $\begin{array}{l}-2.963539^{*} \\
(0.0002)\end{array}$ \\
\hline$D_{i j}$ & $\begin{array}{l}-9.36583^{* *} \\
(0.0144)\end{array}$ & $\begin{array}{l}-14.72237^{*} \\
(0.0001)\end{array}$ & $\begin{array}{c}-25.68694^{*} \\
(0.0000)\end{array}$ & $\begin{array}{l}-22.61019^{*} \\
(0.0000)\end{array}$ & $\begin{array}{c}-11.82369^{*} \\
(0.0016)\end{array}$ \\
\hline$t_{i}$ & $\begin{array}{c}-3.76136^{* *} \\
(0.0233)\end{array}$ & $\begin{array}{c}0.316496 \\
(0.8765)\end{array}$ & $\begin{array}{c}-0.251970 \\
(0.8567)\end{array}$ & $\begin{array}{c}-1.642878 \\
(0.2389)\end{array}$ & $\begin{array}{c}0.621297 \\
(0.5617)\end{array}$ \\
\hline$t_{j}$ & $\begin{array}{c}-0.305202 \\
(0.7206)\end{array}$ & $\begin{array}{c}-1.806658 \\
(0.3771)\end{array}$ & $\begin{array}{c}-1.943383 \\
(0.1709)\end{array}$ & $\begin{array}{c}-0.627888 \\
(0.6579)\end{array}$ & $\begin{array}{c}-2.221986^{* *} \\
(0.0291)\end{array}$ \\
\hline$e x_{i}$ & $\begin{array}{c}-3.252881^{*} \\
(0.0006)\end{array}$ & $\begin{array}{c}2.799426^{*} \\
(0.0043)\end{array}$ & $\begin{array}{c}1.504422^{*} \\
(0.0000)\end{array}$ & $\begin{array}{c}1.318602^{*} \\
(0.0003)\end{array}$ & $\begin{array}{c}0.603673^{* *} \\
(0.0367)\end{array}$ \\
\hline$e x_{j}$ & $\begin{array}{c}5.228125^{*} \\
(0.0000)\end{array}$ & $\begin{array}{c}-2.308180^{* * *} \\
(0.0592)\end{array}$ & $\begin{array}{c}0.405594 \\
(0.1786)\end{array}$ & $\begin{array}{c}0.483447 \\
(0.2050)\end{array}$ & $\begin{array}{c}1.212119^{*} \\
(0.0002)\end{array}$ \\
\hline N. Adj. $R^{2}$ & $\begin{array}{c}63 \\
0.607047\end{array}$ & $\begin{array}{c}63 \\
0.544942\end{array}$ & $\begin{array}{c}63 \\
0.741487\end{array}$ & $\begin{array}{c}63 \\
0.701265\end{array}$ & $\begin{array}{c}63 \\
0.795372\end{array}$ \\
\hline
\end{tabular}

With respect to GDP per capita as one ofthe primary variable, the table 7shows the significance estimationfor Indonesia, Philippines, Singapore and Thailand. Nonetheless, the symbol of GDP notation for each country is a negative. It implies between Indonesia and these countries as mentioned from pervious statement have strong trade flows each other. Consider Indonesia to Singapore, Indonesia might be imported by around $4.43 \%$ of finished agro basedproducts from Singapore to fulfill the domestic consumption. Indonesia is taking the percentage of $3.1 \%$ from the total production of Indonesia agro based-products into account of export to Singapore. The material of export could be a lot of portion of raw material whether to process or to consume by Singapore.

Furthermore, the Philippines is identifying as the most expensive country cost of relatedtrading. Therefore, the Indonesia producers are suggested to provide a special budget to treat the trade expenses to Philippines as percentage of $25.68 \%$ from the total transaction. Table 7 also contains the information due to the cost of import (ACEPT). Nevertheless, none the country reveals the significance estimation. By that, there is no more analysis relate to this parameter. This paper found the significance estimation exchange rate of IDR against Malaysia Ringgit (RMY). Once IDR is appreciated to RMY, Indonesia's trade balance of agro based-products is probably deficit up to $0.48 \%$. The notation of the adjusted $R^{2}$ is summarized that all the selected members as Indonesia partner of trading denote there are a huge transaction in AFTA in terms of agro based-products. 
Table 8 given information about the significance of GDP estimation for all members without Brunei. To the extent of the significance GDP estimation, in case Indonesia against Philippines conveys an examination that since Indonesia possesses the negative notation therefore Indonesia implies as an importer. So that it allows Philippines to convey its fisheries to Indonesia by around $4.5 \%$ from its total capacity. Surprisingly, there is a surplus transaction cost relatedtrade to Brunei, Malaysia, and Singapore. It might be these countries producers pro active to send the crew to take away fisheries products live from Indonesia.

It is noticeable that only between Indonesia and Thailand induce the significance estimation of notation tariff of trade. Moreover, from the regressed result that the negative sign incurs the lower Indonesia tariff than Thailand. Hence, it is suggested more suitable being an importer and more properly utilizing a trade creation strategy to face Thailand. Thus, Indonesia producers might be decreased up to $3.5 \%$ in order to equally their price with the price of final product of fisheries from Thailand. Unless for raw and intermediated goods, the Indonesia producers may enjoy the surplus therefore the lower price from Thailand. The Indonesia consumers are having the surplus up to 3.5\% whether fisheries from domestic or from Thailand. However, Indonesia government linkages to the tariff revenue from the fisheries of Thailand Indonesia government slightly fall by around 3.5\%.

\begin{tabular}{|c|c|c|c|c|c|}
\hline \multicolumn{6}{|c|}{$\begin{array}{l}\text { Table } 8 . \\
\text { A Modified Gravity Equation Estimated for Fisheries Sector }\end{array}$} \\
\hline Indonesia to: & Brunei & Malaysia & Philippines & Singapore & Thailand \\
\hline Constanta & $\begin{array}{l}-54.18927^{*} \\
(0.0000)\end{array}$ & $\begin{array}{c}-32.76588^{*} \\
(0.0027)\end{array}$ & $\begin{array}{c}8.482359 \\
(0.4249)\end{array}$ & $\begin{array}{l}-22.82341^{* *} \\
(0.0633)\end{array}$ & $\begin{array}{c}4.363658 \\
(0.7965)\end{array}$ \\
\hline$Y_{i}$ & $\begin{array}{c}8.462536^{*} \\
(0.0000)\end{array}$ & $\begin{array}{l}-12.14327^{*} \\
(0.0000)\end{array}$ & $\begin{array}{l}-2.911854^{*} \\
(0.0000)\end{array}$ & $\begin{array}{l}-3.033221^{*} \\
(0.0000)\end{array}$ & $\begin{array}{c}-2.538768^{*} \\
(0.0001)\end{array}$ \\
\hline$Y_{j}$ & $\begin{array}{c}-0.955361 \\
(0.4746)\end{array}$ & $\begin{array}{c}17.36504^{*} \\
(0.0000)\end{array}$ & $\begin{array}{c}4.468222^{*} \\
(0.0000)\end{array}$ & $\begin{array}{c}4.960436^{*} \\
(0.0000)\end{array}$ & $\begin{array}{l}4.601110^{*} \\
(0.0000)\end{array}$ \\
\hline$D_{i j}$ & $\begin{array}{c}10.08323^{*} \\
(0.0004)\end{array}$ & $\begin{array}{l}5.443870^{* * *} \\
(0.0365)\end{array}$ & $\begin{array}{l}-2.647054 \\
(0.2969)\end{array}$ & $\begin{array}{l}6.318731^{* *} \\
(0.0469)\end{array}$ & $\begin{array}{l}-2.040497 \\
(0.6337)\end{array}$ \\
\hline$t_{i}$ & $\begin{array}{c}4.591401^{*} \\
(0.0002)\end{array}$ & $\begin{array}{c}-0.890421 \\
(0.5565)\end{array}$ & $\begin{array}{c}-0.269143 \\
(0.8274)\end{array}$ & $\begin{array}{c}-0.899342 \\
(0.4352)\end{array}$ & $\begin{array}{c}-3.535508^{*} \\
(0.0079)\end{array}$ \\
\hline$t_{j}$ & $\begin{array}{c}0.569777 \\
(0.3563)\end{array}$ & $\begin{array}{c}3.424231^{* * *} \\
(0.0273)\end{array}$ & $\begin{array}{c}2.493441^{* *} \\
(0.0494)\end{array}$ & $\begin{array}{c}2.755098^{* *} \\
(0.0226)\end{array}$ & $\begin{array}{c}5.750686^{*} \\
(0.0000)\end{array}$ \\
\hline$e x_{i}$ & $\begin{array}{c}-1.322690^{* *} \\
(0.0426)\end{array}$ & $\begin{array}{c}2.656597^{*} \\
(0.0004)\end{array}$ & $\begin{array}{c}0.506773^{* *} \\
(0.0356)\end{array}$ & $\begin{array}{c}-0.142433 \\
(0.6105)\end{array}$ & $\begin{array}{c}0.620905^{* * *} \\
(0.0717)\end{array}$ \\
\hline$e x_{j}$ & $\begin{array}{c}1.701005^{* *} \\
(0.0356)\end{array}$ & $\begin{array}{c}-3.775544^{*} \\
(0.0001)\end{array}$ & $\begin{array}{c}-0.092481 \\
(0.7265)\end{array}$ & $\begin{array}{c}0.483130 \\
(0.1283)\end{array}$ & $\begin{array}{c}-0.400784 \\
(0.2780)\end{array}$ \\
\hline N. Adj. $R^{2}$ & $\begin{array}{c}63 \\
0.76646\end{array}$ & $\begin{array}{c}63 \\
0.713238\end{array}$ & $\begin{array}{c}63 \\
0.768666\end{array}$ & $\begin{array}{c}63 \\
0.764817\end{array}$ & $\begin{array}{c}63 \\
0.662725\end{array}$ \\
\hline
\end{tabular}

Regarding exchange rate between Indonesia and Malaysia, the IDR indicates appreciated over the RMY and as a consequence may affecting the decreasing of Indonesian net export on fisheries by about $1.11 \%$. 
The adjusted $R^{2}$ determines the degree of the fisheries trade between Indonesia and its partner of selected member of AFTA. The value of adjusted $R^{2}$ implies that each selected country points out as a highly important to an intended objective for Indonesia in terms of AFTA.

\section{CONCLUSION}

Overall, from the empirical standpoint of the dynamics finding indicates that the some noted. The objective of trade flow is addressed to gain magnitude beneficial for Indonesia nexus the AFTA. The beneficial can be come up ultimately from the factor of the natural competitive advantage by employing GDP as a proxy of this factor. Actually, based on the findingof estimation GDP, in as much, Indonesia might be concluded as the country which exposing the strength of the natural competitive advantage instead of the others. Such sectors are already mentioned in analysis on empirical findings and discussion. Next, the factor of the tariffs of free trade effect will relevant to in the applied of the strategy either a trade creation or a trade diversion. Rely on both strategies, the rubber based-products sector, Indonesia may implement a trade creation only to Thailand in order to gain from free trade.

On the wood based-products, Indonesia may utilize both trade creation and trade diversion to Malaysiadepends upon which one is more beneficial for Indonesia. Nonetheless, nothing gain can found from the tariff of trade linkage to agro-based products. Once again Thailand is become an advantageous partner for Indonesia in terms of fisheries sector. Indonesia may apply the trade creation in order to bolster the volume of trade with Thailand. The finding of the adjusted $R^{2}$ might interpret as a whole by doing such free trade with particular selected ASEAN member, Indonesia is expected to earn the greater amount of surplus. Hence, for the rubber based-products sector, Indonesia may direct its trade flows more concerning to Thailand rather than others. In the context of the wood based-products, Brunei is exclusion but the rest is strategic for Indonesia. For instance, Indonesia should extensively engage of trading with each selected members regarding the agro based-products sector and the fisheries sector.

By and large, this paper suggests that if Indonesia has a goal being the key player in the foreseeable AFTA therefore Indonesia should rocketed its infrastructure to back up its trade and then increasing sharply its GDP per capita, minimizing the trade barrier and cost, and managing the exchange rates as well. Hereafter, the relative beneficial can be aimed by Indonesia according 2015.

Note: please put the panelist comment for future studies here. 


\section{REFERENCES}

Aczel, D., Amir, (1995), Statistics Concepts and Applications, Irwin.

ASEAN Economic Community Blueprint. "ASEAN Secretariat", Jakarta, January 2008.

ASEAN Economic Community Chartbook. "ASEAN Secretariat", Jakarta, September, 2009.

ASEAN. "ASEAN Free Trade Area (AFTA Council)"http://www.asean.org/19585.htm., October 2010.

Balassa, Bela. "Trade Creation and Trade Diversion in the EEC", Economic Journal, No. 77, p121, 1967.

Brada, Josef C and Mendez, Jose A. "Economic Integration Among Developed, Developing and Centrally Planned Economies : A Comparative Analysis", The Review of Economics and Statistics, 1985.

Calvo-Pardo, Hector., Freund, Caroline., and Ornelas, Emanuel. "The ASEAN Free Trade Agreement: Impact on Trade Flows and External Trade Barriers". Policy Research Working Paper The World Bank Development Research Group Trade and Integration Team, 2009.

Dodge, David. "Economic Integration in North America", Bank of Canada Review, 2003.

El-Agraa, Ali M, (1997), Economic Integration Worldwide, St Martins Press, New York.

Gujarati, N., Damodar and Porter, C., Dawn, (2009), Basic Econometrics, Fifth Edition, McGraw-Hill International Edition.

Husted, Steven and Melvin, Michael, (2010), International Economics, Eight Edition, AddisonWesley.

Indonesian and Bali on the net.http://www.indo.com/distance, October 2010.

Krugman, Paul R. and Maurice Obstfeld, (2009), International Economics: Theory and Policy, Eight Edition, Addison-Wesley.

Market Analysis and Research, International Trade Center. "Trade Map" http:// www.trademap.org/selectionmenu.aspx, October 2010.

Pacheco, Amurgo., Alberto and Pierola, Denisse., Martha. "Patterns of ExportDiversifcation in Developing Countries: Intensive and Extensive Margins". Policy Research Working Paper, 4473, The World Bank International Trade Department, 2008. 
Pelkmans, Jacques, (2006),European Integration: Method and Economic Analysis, Third Edition, Pearson Education Limited.

Tamirisa, T., Natalia. "Exchange and Capital Controls as Barriers to Trade". IMF working paper, 1999.

Venables. J, Anthony. "International Trade; Regional Economic Integration", The International Encyclopedia of Social and Behavioral Sciences, Article 34), London School of Economics, 2000.

Zarzoso, Martines., Inmaculada." Gravity Model: An Application to Trade Between Regional Blocs", Atlantic Economic Journal, 2003. 